\title{
THE TOURIST DEMAND FROM THE PERSPECTIVE OF THE MOTIVATION, ASSESSMENT AND SATISFACTION IN A SUN AND BEACH DESTINATION: THE MANTA CASE, ECUADOR
}

\author{
Mauricio CARVACHE-FRANCO \\ Espíritu Santo University-Ecuador, Av. Samborondón, \\ Samborondón 092301, Ecuador, e-mail: mauricio2714@hotmail.com

\section{Orly CARVACHE-FRANCO} \\ Catholic University of Santiago de Guayaquil, Faculty of Business Specialties, \\ Av. Carlos Julio Arosemena Km 1.5, Guayaquil, Ecuador, e-mail: orly.carvache@cu.ucsg.edu.ec

\section{Wilmer CARVACHE-FRANCO*} \\ ESPOL Polytechnic University, Escuela Superior Politécnica del Litoral, ESPOL, \\ Faculty of Social Sciences and Humanities, Campus Gustavo Galindo Km 30.5 Vía Perimetral, \\ P.O. Box 09-01-5863, Guayaquil, Ecuador, e-mail: wcarvach@espol.edu.ec
}

\section{Cesar VILLAGóMEZ BUELE}

University of Guayaquil, Faculty of Chemical Engineering, Malecón del Salado between Av. Delta and Av. Kennedy, Guayaquil, Ecuador, e-mail: cesar.villagomezb@ug.edu.ec

\section{Marina ARTEAGA PEÑAFIEL}

University of Guayaquil, Faculty of Chemical Engineering, Malecón del Salado between Av. Delta and Av. Kennedy, Guayaquil, Ecuador, e-mail: marina.arteagap@ug.edu.ec

Citation: Carvache-Franco, M., Carvache-Franco, O., Carvache-Franco, W., Villagómez Buele, C., \& Arteaga Peñafiel, M. (2018). THE TOURIST DEMAND FROM THE PERSPECTIVE OF THE MOTIVATION, ASSESSMENT AND SATISFACTION IN A SUN AND BEACH DESTINATION: THE MANTA CASE, ECUADOR. GeoJournal of Tourism and Geosites. 22(2), 561-572. https://doi.org/10.30892/gtg.22224-311

\begin{abstract}
Conducting studies of motivation, evaluation and satisfaction of the demand of sun and beach tourism provides important information to adapt the products according to demand. The present study was conducted in situ in the city of Manta, Ecuador. Using a questionnaire, variant and bivariate statistical techniques were used to achieve the study objectives. The findings show that the main motivations of tourists are to rest, enjoy the beach and the sun, and enjoy the typical local gastronomy, which ratifies the main motivations in destinations with these characteristics. The most valuable aspects of the visit were the hospitality of the residents, the sun and the beach, and the restaurant service. The satisfaction of the destination is high, which shows the potential of this site for this type of tourism.
\end{abstract}

Key words: Tourism, demand, motivation, satisfaction, assessment, Manta

\footnotetext{
* Corresponding author
} 


\section{INTRODUCTION}

Sun and beach tourism has had a growth of $39 \%$ between 2007 to 2014, this type of tourism is the most attractive for visitors because of the natural characteristics of the destinations, occupying the best segment of the tourism market with 29\% (ITB World Travel Trends Report 2015/2016), the US and Asian market has driven 6\% growth between January and August 2016 (ITB World Travel Trends Report 2016/2017), so it is essential to raise an inquiry about of the sun and beach destinations that contribute to improve the provision according to demand. In this sense, vacationing on the beach is becoming a phenomenon of mass tourism (Bramwell, 2004). Consequently, Poon (1993) sought to change the stereotype 3-S (sun, sand and sex) to a more exclusive and strict tourist, who seeks more than a break. For the above reasons, Orams \& Lück (2013) ratify that the distraction on the beach is destined to prosper in the future.

Manta is the first fishing port and maritime of Ecuador; the tourist offer is varied, has food and beverage establishments, accommodation, entertainment and sports centers. You can perform different types of tourism like gastronomic, cultural, religious, sun and beach, adventure, meetings and ecotourism. It has the Pacoche Marine Coastal Wildlife Refuge; it has cozy beaches such as the Murciélago, Barbasquillo, San Mateo, San Lorenzo where you can practice water and recreational sports, you can also enjoy artistic and cultural events. The restaurants offer gastronomy based on seafood; while crafts made with local products are sold in pier. In this context, it is important to carry out studies that analyze tourism demand from the perspective of motivation, assessment and satisfaction in sun and beach destinations such as the case of Manta in Ecuador, due to its natural and cultural characteristics typical of this type of tourism; that is why this tourist destination is very visited by national and foreign tourists. At present, there has not been a study that addresses this issue; that is why the objective of this study is to present the results of a field work that addresses a study of the motivations, valuation and satisfaction of tourism demand. The present research aims to achieve this objective and consists of the following parts: the introduction, followed by the review of the literature, then describing the characteristics of the destination, the methodology of the research and the results. The article ends with the conclusions and the bibliography used.

\section{THEORETICAL FRAMEWORK}

The field of motivations is increasingly studied in relation to tourism demand, so mmotivations is a set of biological and spiritual needs and wants that motives one to do specific tasks (Crompton \& McKay, 1997). Therefore, it is the central factor in the decision-making process (Yolal et al., 2015). If we refer to the motivations of tourists, these can be divided into two main categories: content models and process models (Hsu et al., 2010; Suni \& Komppula, 2012). Content models, in the context of various conceptualizations of needs, are proposed in the form of different models such as Maslow's theory of the hierarchy of needs (1943) two-factor theory of motivation-hygiene, and Plog's (1974) theory of Allocentric- Psychocentric spectrum. Regarding the process models, these include those that address behavior predictions after one has been motivated. Dann's (1977) theory of pull-push factors and Crompton's (1979) theory of motivation which was further developed by Iso-Ahola (1982) are placed in this category. Process models are more central than content models and have a better ability in predicting behavior (Hsu et al., 2010). These models are mostly used. Thus, it can be said that tourists' motivations are usually complex and multi-dimensional (Crompton, 1979; Uysal et al., 1993). In the tourism sector, the main motivations of the sun and beach tourist are rest and recreation, since it is included in leisure tourism (Martínez, 2001; 
The tourist demand from the perspective of the motivation, assessment and satisfaction in a sun and beach destination: The Manta case, Ecuador

Rivas, 2004; Bigné et al., 2007). In this sense, for González et al. (2006) the main motivations of sun and beach tourists are rest and relaxation, followed by fun and entertainment. In the same line, for Carvache-Franco et al. (2017), Enjoy the sun and the beach, and rest were the main motivations. In another study, Prebensen et al. (2010) uses two motivational dimensions in sun and beach destinations: Body-related (Sun and warmth-related motivations, and Fitness and health-related motivations) in the Mindrelated (Culture and nature-related motivations, and Escapism-related motivations).

About the motivations in coastal marine destinations: Kozak (2002) on the tourists' trip to Mallorca (Spain) revealed reasons such as culture, pleasure / fantasy, relaxation and physics. Molera and Abaladejo (2007) identified five marine reasons for traveling to Murcia-Spain, nature and tranquility, physical and cultural activities, family, travel characteristics and rural life. In another study, Saayman et al. (2009) found five travel motivation factors for marine destinations in South Africa: escape and relaxation, destination attractiveness, socialization, personal attachment, site attributes and trip features. In another study, Kruger and Saayman (2010) found six reasons to travel for tourists visiting Tsitsikamma National Park, located in the Indian Ocean in South Africa, which were as knowledge seeking, nature experience, photography, escape and relaxation, park attributes and nostalgia. In another research (Van Der Merwe et al., 2011) on coastal marine destinations found four motivational factors: Destination attractiveness (Factor 1), Escape and relaxation (Factor 2), Time utilization (Factor 3) and Personal attachment (Factor 4). For De Nisco et al. (2015) different destinations have different reasons for traveling, finding in a study carried out in Africa the same motivations as escape and relaxation, destination attractiveness, and site attractiveness as well as personal attachment and different motivations, for Jeffreys Bay, however, leisure activities and novelty were identified and for Hartenbos, socialization and trip features as additional motives for traveling. In this framework of ideas, marketing focuses on the customer, and relies on administrative processes to make promises or value propositions that reflect individual expectations created by such proposals and their fulfillment is done through the creation of value (Grönroos, 2009). In this sense, factors such as the satisfaction of tourists as a result of the co-creation of services, contribute to the attractiveness of a tourist region, with which the key areas are effectively traced to make, enable and keep promises to tourists (Dolnicar \& Ring, 2014). Thus, the study of tourists in a comprehensive manner is necessary to understand their level of satisfaction, as it is evident that this depends on the profile of the visitor, as well as social, financial elements and the environment in which it is related (Torres-Sovero et al., 2012).

On the other hand, the scientific literature recognizes the importance of satisfaction to recommend a destination (Hosany \& Witham, 2010), the positive effect it causes when relating it with the intention to return (Zabkar et al., 2009; Chen \& Chen, 2010), and for being considered as a moderating part of the image of destination (Chi \& Qu, 2008). From another perspective, Das Chagas and Marques Júnior (2011) consider that there are eight perceived dimensions of quality in sun and beach destinations: beaches and facilities, public facilities, food and beverages, transportation services, hotel facilities, services of the hotel, entertainment and attractions, and hospitality and access.

For them it is necessary to provide a quality of service, the relationship between the quality of the image of a destination and tourist satisfaction is well documented in the tourism field (Chen \& Chen, 2010, Yüksel et al., 2010; Žabkar et al., 2010; Moliner Velázquez et al., 2011; Cong, 2016). Therefore, it is necessary to analyze variables directly related to the natural environment, the services offered within the destination and its amenities (Safee Sapari et al., 2013). Therefore, it is very important to analyze these 
aspects in sun and beach destinations in order to improve the quality of tourist services. Regarding the assessment of sun and beach destinations, in a study (Carvache-Franco et al., 2018) the variables best valued in General Villamil Playas from Ecuador were the "sun and the beach"," Restaurant services "," hospitality of residents ", and "accommodation ".

\section{CHARACTERIZATION OF MANTA DESTINATION}

This aboriginal capital of the Manteña Culture was baptized on March 2, 1534 as "San Pablo de Manta", it happened to occupy the place of seaport, then it was a cabotage port. During the Presidency of the Republic of Ecuador, Vicente Rocafuerte designated it as the First Maritime Port of Ecuador in 1837. Finally, in the administration of General Juan José Flores, it was qualified as an export and import port (Sánchez, 2010). Manta is located in the most western salient of South America, limits to the west with the Pacific Ocean, to the south with Montecristi and to the east with Montecristi and Jaramijó; the temperature fluctuates between $18^{\circ} \mathrm{C}$ and $36^{\circ} \mathrm{C}$ (Figure 1).

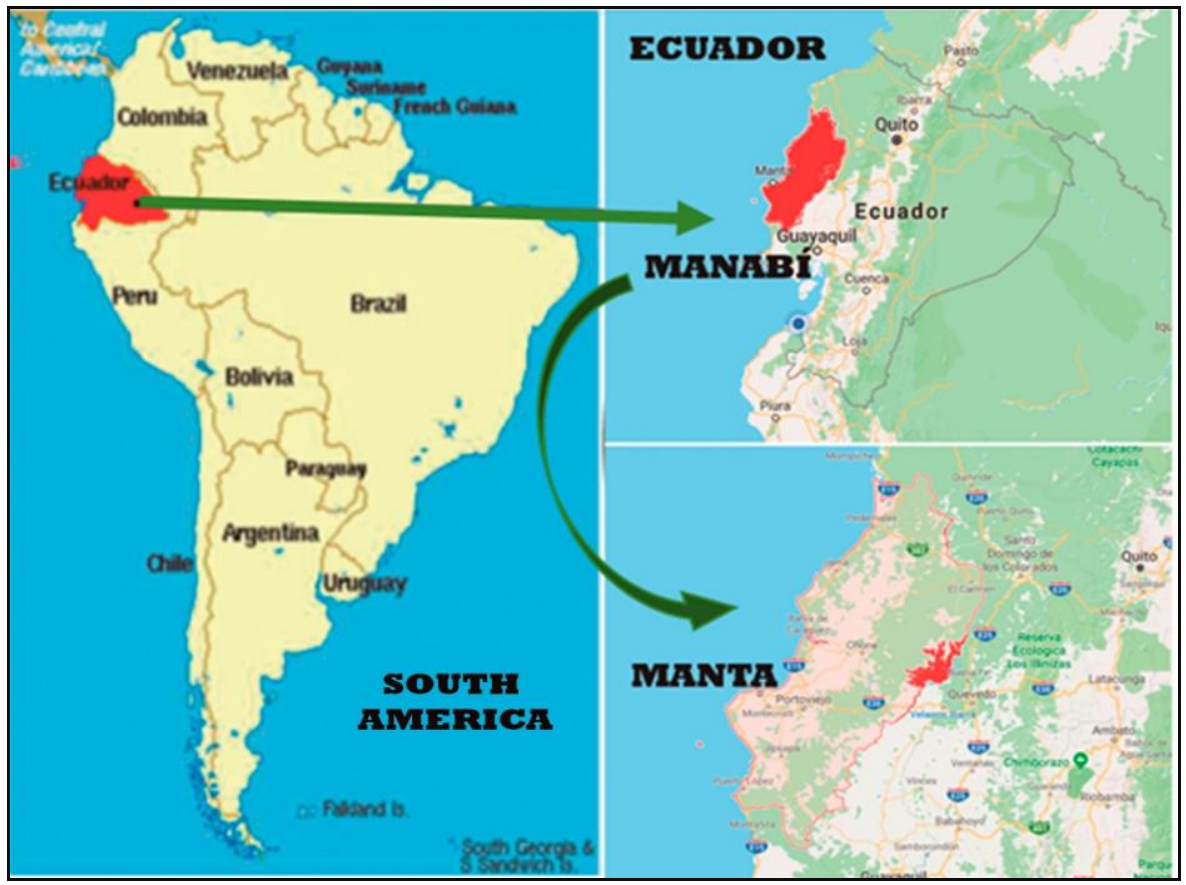

Figure 1. Geographic Location of Manta (Ecuador) in South America

According to Decentralized Autonomous Government of Manta (2016), it has an area of 29,265.96 ha, distributed as follows: $70.60 \%$ Natural Vegetable Coverage, $15.44 \%$ anthropic use, 3.96\% livestock use, 5.27\% agricultural and mixed agricultural use and 4.73\% are unproductive land. Manta energizes the economy of Manabí province - Ecuador, both for the amount of productive units and active services, as for the volume of the total production and its contribution in the formation of Gross domestic product (GDP). (Decentralized Autonomous Government of Manta, 2016) In Malecón sector, the commercial area and hotel chains are concentrated, Tarqui parish sells fishing products and in the urban area there are tourist, commercial, banking and industrial companies. The city also has museums where archaeological fragments of cultures of the region are exhibited. 
The Decentralized Autonomous Government of Manta (2016) declared Furniture Cultural Heritage to 38 monuments and 29 real estate as Cultural Patrimony of the Nation.

\section{METHODOLOGY}

In order to reach the proposed objectives, an on-site fieldwork was carried out based on a survey that contained 17 questions grouped into two blocks: (sociodemographic information and the satisfaction and motivation of the visitors) whose target population were older visitors of 18 years. Closed and multiple-choice questions on a fivepoint Likert scale were used to obtain reliable results. The data collected were organized, tabulated and analyzed through the SPSS Version 22 program, univariate and bivariate statistical instruments were also used. Visitors were surveyed near the Murciélago beach in Manta city during weekends between March and April 2018. The surveys were conducted by students of the bachelor's degree in gastronomy at the University of Guayaquil, who were previously trained by the authors of this article. The sample size was 390 and the infinite population was used considering that the study population is over 10,000 according to the number of tourists who visited Manta in 2015 received 625,000 tourists; in 2016 from January to October received a total of 266,00o tourists (Gobierno Autónomo Descentralizado de Manta, 2016). A margin of error of $+/-5 \%$, a confidence level of $95 \%$ and a variance of $50 \%$ is proposed (Table 1).

Table 1. Research file

\begin{tabular}{ll}
\hline Population & National and foreign visitors \\
Geographic área & Manta city \\
Period of realization & March and April 2017 \\
Process & Simple random sampling \\
Confidence level & $95 \%$ \\
Error range & $+/-5 \%$ \\
Valid questionnaires & 390 \\
\hline
\end{tabular}

Several previous research papers were reviewed in order to elaborate the questionnaire of questions (Prebensen et al., 2010, Van Der Merwe et al., 2011, De Nisco et al., 2015, Carvache-Franco et al, 2018), where you can see relevant research on motivation, assessment and satisfaction of demand in sun and beach destinations. The cronbach alpha index reached the value of 0.83 , which indicates a meritorious internal consistency between the elements of the scale.

\section{RESULTS AND DISCUSSION}

The results of socioeconomic variables as gender, age, civil status, level of education and professional activity are found in Table 2.

Table 2. Socioeconomic variables

\begin{tabular}{|l|l|c|}
\hline \multicolumn{2}{|l|}{ Variable } & Percentage \\
\hline \multirow{4}{*}{ Gender } & Man & 48.7 \\
\cline { 2 - 3 } Age & Woman & 51.3 \\
\hline \multirow{4}{*}{} & Younger than 20 & 6.4 \\
\cline { 2 - 3 } & Among 20 - 29 & 35.6 \\
\cline { 2 - 3 } & Among 30-39 & 32.1 \\
\cline { 2 - 3 } & Among 40-49 & 14.4 \\
\cline { 2 - 3 } & Among 50-59 & 10.0 \\
\cline { 2 - 3 } & Older than 60 & 1.5 \\
\hline
\end{tabular}


Mauricio CARVACHE-FRANCO, Orly CARVACHE-FRANCO,

Wilmer CARVACHE-FRANCO, Cesar VILLAGÓMEZ BUELE, Marina ARTEAGA PEÑAFIEL

\begin{tabular}{|c|c|c|}
\hline \multirow{5}{*}{ Civil Status } & Single & 42.6 \\
\hline & Free Union & 26.9 \\
\hline & Widowed & 1.3 \\
\hline & Married & 27.4 \\
\hline & Divorced & 1.8 \\
\hline \multirow{4}{*}{$\begin{array}{l}\text { Level of } \\
\text { Education }\end{array}$} & Primary education & 3.6 \\
\hline & Secondary education & 39.0 \\
\hline & University education & 56.4 \\
\hline & Postgraduate/master's degree / Ph.D. & 1.0 \\
\hline \multirow{10}{*}{$\begin{array}{c}\text { Professional } \\
\text { Activity }\end{array}$} & Student & 25.1 \\
\hline & Businessman, business owner & 11.3 \\
\hline & Public employee & 13.1 \\
\hline & Private employee & 10.0 \\
\hline & Independent employee & 6.4 \\
\hline & Housework & 11.0 \\
\hline & Unemployed & 7.4 \\
\hline & Retired & 3.6 \\
\hline & Informal worker & 7.4 \\
\hline & Others & 0.0 \\
\hline
\end{tabular}

According to the results from Table 2, 48.7\% of the visitors are men and $51.3 \%$ are women, what shows that visitors from both genders arrive the destination, from which, $35.6 \%$ have an average age of 20 to 29 years old and $32.1 \%$ have an average age of 30 to 39 years old. About the civil status, $42.6 \%$ are single and $27.4 \%$ are married. Concerning the level of education, a $56.4 \%$ have a university education and $39.0 \%$ have a secondary education, being $\mathbf{2 5 . 1 \%}$ students as the majority group, followed by public employees with a $13.1 \%$ of the total amount of respondents.

To know what company tourists prefer when visiting a place, Table 3 is shown.

Tabl 3. Who the tourist travels with

\begin{tabular}{|l|c|c|}
\hline \multicolumn{1}{|c|}{ Variable } & Percentage & Ranking \\
\hline With family & 52.3 & 1 \\
\hline With friends and coworkers & 35.4 & 2 \\
\hline With the couple & 10.3 & 3 \\
\hline Alone & 1.3 & 4 \\
\hline Others & 0.8 & 5 \\
\hline
\end{tabular}

According to the results from Table 3, tourists use to travel to this destination with their families (52.3\%), with friends and coworkers (35.4\%), which indicates that Manta is generally a destination to go with the family principally, followed by groups of friends. The frequency the visitors arrive to the destination is presented in Table 4, where the frequency in this destination is from 1 to 3 times a year (43.6\%) and from 4 to 6 times a year (41.8\%).

Table 4. Frequency of visit

\begin{tabular}{|c|c|c|}
\hline Frequency of visit & Frequency & Percentage \\
\hline From 1 to 3 times a year & 170 & 43.6 \\
\hline From 4 to 6 times a year & 163 & 41.8 \\
\hline From 7 to 9 times a year & 57 & 14.6 \\
\hline Total & $\mathbf{3 9 0}$ & $\mathbf{1 0 0}$ \\
\hline
\end{tabular}


The tourist demand from the perspective of the motivation, assessment and satisfaction in a sun and beach destination: The Manta case, Ecuador

\section{Motivations}

Tourists' motivations are shown in Table 5 . It is based on a 5 points Likert scale, being 1 - the less and 5 - the most.

Table 5. Motivations

\begin{tabular}{|l|c|c|}
\hline \multicolumn{1}{|c|}{ Motivational variables } & Mean & Ranking \\
\hline Resting & 4.63 & 1 \\
\hline Enjoying beach and sun & 4.58 & 2 \\
\hline Delight with local typical gastronomy & 4.24 & 3 \\
\hline Visiting touristic attractions & 4.18 & 4 \\
\hline Night life & 3.84 & 5 \\
\hline Visiting friends or family & 3.79 & 6 \\
\hline Because of touristic services prices & 3.78 & 7 \\
\hline To know flora and fauna & 3.77 & 8 \\
\hline For its commercial activity & 3.59 & 9 \\
\hline For visiting communities & 3.40 & 10 \\
\hline Closeness to your residence place & 3.13 & 11 \\
\hline
\end{tabular}

As shown in Table 5, the principal motivations of tourists in visiting the destination are resting (4.63), enjoying beach and sun (4.58), delight with local typical gastronomy (4.24) and for its night life (3.62). Similar results (Martínez, 2001; Rivas, 2004; González et al., 2006; Bigné et al., 2007; Carvache-Franco et al., 2017) where the resting is one of the main motivations in this type of tourism. These results show that Manta is a destination of sun and beach where its main motivation is rest, with a delicious typical gastronomy. Based on the two motivational dimensions in the sun and beach destinations found by Prebensen et al. (2010) have been found in the present study the motivations related to the Body: rest, and enjoy the sun and the beach. The motivations found related to the mind were: nightlife and to visit friends or family.

The valuation of the sun and beach in different aspects in Manta are shown in Table 6. It is based on a 5 points Likert scale, being 1 - the worst and 5 - the best.

Table 6. Valuation of the destination

\begin{tabular}{|l|r|c|}
\hline \multicolumn{1}{|c|}{ Aspects } & Mean & Ranking \\
\hline Residents' hospitality & 4.56 & 1 \\
\hline Sun and beach & 4.53 & 2 \\
\hline Restaurant service & 4.51 & 3 \\
\hline Accommodation & 4.39 & 4 \\
\hline Security & 4.32 & 5 \\
\hline Touristic services prices & 4.17 & 6 \\
\hline Parking lots & 4.15 & 7 \\
\hline Information and signaling & 4.12 & 8 \\
\hline Commercial zones & 4.11 & 9 \\
\hline Ambient conservation & 4.09 & 10 \\
\hline Recreation places & 4.05 & 11 \\
\hline Cultural activities & 3.91 & 12 \\
\hline Flora and fauna & 3.87 & 13 \\
\hline
\end{tabular}

According to Table 6, the variables with the major valuation were residents' hospitality (4.56), sun and beach (4.53), restaurant service (4.51), accommodation (4.39) and security (4.32). Similar results to the dimensions found by Das Chagas and Marques Júnior (2011) who consider that there are eight perceived quality dimensions in sun and 
beach destinations. In the study of Carvache-Franco et al. (2018) similar results were obtained what would seem to indicate the most valued aspirations in a sun and beach destination. Because the destination also has potential for gastronomy, we must also highlight the need for destination marketing organizations to pay more attention to the link between the destination image and food events (Privitera et al., 2018).

By contrast, the variables with the minor valuation were the flora and fauna (3.87), recreation places (4.05) and the ambient conservation (4.09). These findings indicate this destination has a lot of potential in its beach, which is its principal touristic attraction, also its gastronomy based on seafood, and the hospitality of its residents.

\section{General satisfaction}

Tourist' general satisfaction in the destination is shown in Table 7.

Table 7. General satisfaction in the destination

\begin{tabular}{|c|c|c|c|c|c|}
\hline $\begin{array}{c}\text { Very } \\
\text { unsatisfied }\end{array}$ & Unsatisfied & $\begin{array}{c}\text { Not satisfied } \\
\text { not unsatisfied }\end{array}$ & Satisfied & $\begin{array}{c}\text { Very } \\
\text { satisfied }\end{array}$ & $\begin{array}{c}\text { Mean of } \\
\text { satisfaction }\end{array}$ \\
\hline $0.5 \%$ & $0.0 \%$ & $3.3 \%$ & $20.8 \%$ & $75.4 \%$ & 4.71 \\
\hline
\end{tabular}

According to Table 7, 75.4\% of the tourists are very satisfied, with the destination, while a $20.8 \%$ are satisfied; this indicates a great percentage of the visitors have a good appreciation of the destination. On the other hand, the general satisfaction mean of the tourists if 4.71 which indicates a high satisfaction. These findings are very important to promote the destination based on the general satisfaction of its visitors. The visitors with the major satisfaction and with their expectations surpassed will have a more positive perspective of the place and in consequence major possibilities to return to the destination and also recommend it to other people (Cruz et al., 2012) which demonstrate the high potential of this destination for tourism.

\section{Tourists' information media}

The following Table 8 shows the means of communication that tourists used to obtain information about the destination. The question was of multiple choices, reason why the result is higher than 100.

Table 8. Information Media

\begin{tabular}{|l|c|c|}
\hline \multicolumn{1}{|c|}{ Media } & Percentage & Ranking \\
\hline Friends recommendations & 60.0 & 1 \\
\hline Social media recommendations & 37.4 & 2 \\
\hline Internet based information & 33.6 & 3 \\
\hline Press & 27.9 & 4 \\
\hline Journals & 21.5 & 5 \\
\hline Radio & 16.4 & 6 \\
\hline Others & 10.5 & 7 \\
\hline
\end{tabular}

Table 8, shows that $60 \%$ of the respondents came to know the destination through recommendations from friends, $37.4 \%$ by social media and $33.6 \%$ used the information found on the internet, which indicates the destinations use principally the internet for their publicity, even more than the radio (16.4\%), Journals (21.5\%) and press in general (27.9\%).

\section{Valuation of the experience in Manta}

The following Table 9, shows the valuation of the experience after visiting Manta and its response in recommending the destination or not. For the report in the table it has been taken the media of the valuation from 1 to 5 , where 1 is strongly 
disagree and 5 is strongly agree. According to the exposed on the Table 9, the general valuation of the different questions by the tourists shows a media major to 4.5 , which indicates tourists agree on choosing Manta as a touristic destination (4.58), in their satisfaction they also agree (4.57); they would also recommend visiting Manta (4.71) and encourage their related to travel to the destination (4.65), and most importantly, the visitors would like to return Manta eventually (4.65).

Table 9. Experience valuation

\begin{tabular}{|l|c|c|}
\hline \multicolumn{1}{|c|}{ Valuation } & Mean & Ranking \\
\hline My decision of visiting Manta was right & 4.58 & 1 \\
\hline My satisfaction level with Manta has been important & 4.57 & 2 \\
\hline I would recommend visit Manta if someone asks me for advice & 4.71 & 3 \\
\hline I will encourage my family and/or friend to visit Manta. & 4.65 & 4 \\
\hline After my experience, I think I will return to Manta on a next occasion. & 4.65 & 5 \\
\hline
\end{tabular}

\section{Relationship of satisfaction with the variables of destination}

The relationship of general satisfaction with the different destination variables are presented in Table 10. They have been analyzed through a Spearman correlation.

Table 10. Satisfaction with diferent variables of destination

\begin{tabular}{|l|c|c|}
\hline Aspects & Coefficient & Sig. \\
\hline Security & $0.440^{* *}$ & 0.000 \\
\hline Information and signaling & $0.369^{* * *}$ & 0.000 \\
\hline Restaurant service & $0.337^{* *}$ & 0.000 \\
\hline Recreation places & $0.318^{* *}$ & 0.000 \\
\hline Sun and beach & $0.313^{* * *}$ & 0.000 \\
\hline Accommodation & $0.303^{* *}$ & 0.000 \\
\hline Commercial zones & $0.267^{* *}$ & 0.000 \\
\hline Parking lots & $0.261^{* *}$ & 0.000 \\
\hline Residents' hospitality & $0.258^{* *}$ & 0.000 \\
\hline Touristic services prices & $0.246^{* *}$ & 0.000 \\
\hline Cultural activities & $0.239^{* *}$ & 0.000 \\
\hline Flora and fauna & $0.237^{* *}$ & 0.000 \\
\hline Ambient conservation & $0.208^{* *}$ & 0.000 \\
\hline
\end{tabular}

According to Table 10, all the variables analyzed show a significant and positive correlation with general satisfaction. So, the variables that have a greater influence on overall satisfaction are the security, information and signage, restaurants services and recreation sites, so these variables should be improved and in this way the level of General satisfaction of tourists visiting Manta.

\section{destination}

Relationship of satisfaction with the intention of returning to the

The relationship between the level of satisfaction and the intentions of returning to the destination are presented in Table 11. They have been analyzed through a Spearman correlation. As shown in Table 11, a significance level of less than 0.01 has been obtained, so the intentions of returning to the destination are influenced by satisfaction, in other words, the higher level of satisfaction, the greater intentions of return to the destination. In addition, $64.1 \%$ of tourists in relation to the total of respondents, are very satisfied and with a high intention to return to Manta, so the quality must be improved in the different 
variables of the destination to increase the level of overall satisfaction of tourists and in this way increase the intentions of returning to the destination.

Table 11. Relationship between the degree of satisfaction and the intentions of returning to the destination

\begin{tabular}{|c|c|c|c|c|c|c|c|c|}
\hline $\begin{array}{c}\text { After my experience } \\
\text { I think I will come } \\
\text { back next time }\end{array}$ & \multicolumn{5}{|c|}{ Defree of general satisfaction } & \multirow{2}{*}{ Total } & \multirow{2}{*}{ Coefficient } & \multirow{2}{*}{ Sig. } \\
\cline { 2 - 7 } & $\mathbf{1}$ & $\mathbf{2}$ & $\mathbf{3}$ & $\mathbf{4}$ & $\mathbf{5}$ & & & \\
\hline 1 & $0.50 \%$ & & & & & $0.50 \%$ & & \\
\hline 2 & & & $0.50 \%$ & & & $0.50 \%$ & \\
\hline 3 & & & $2.10 \%$ & $2.10 \%$ & $0.30 \%$ & $4.40 \%$ & \multirow{2}{*}{0.566} & \multirow{2}{*}{0.000} \\
\hline 5 & & & $0.80 \%$ & $11.30 \%$ & $11.00 \%$ & $23.10 \%$ & \\
\hline Total & & & & $7.40 \%$ & $64.10 \%$ & $71.50 \%$ & & \\
\hline
\end{tabular}

\section{Relationship of the satisfaction with main motivations}

The relationship with general satisfaction with main motivations are shown in Table 12. They have been analyzed through a Spearman Correlation.

Tabla 12. Relationship of the satisfaction with main motivations of tourists

\begin{tabular}{|c|c|c|c|c|c|c|c|c|c|}
\hline \multirow{2}{*}{\multicolumn{2}{|c|}{ Motivations }} & \multicolumn{5}{|c|}{ Degree of general satisfacction } & \multirow{2}{*}{ Total } & \multirow{2}{*}{ Coefficient } & \multirow{2}{*}{ Sig. } \\
\hline & & $\mathbf{1}$ & 2 & 3 & 4 & 5 & & & \\
\hline \multirow{5}{*}{ For resting } & 1 & & & & & & & \multirow{6}{*}{0.273} & \multirow{6}{*}{0.000} \\
\hline & 2 & & & & $0.3 \%$ & & $0.3 \%$ & & \\
\hline & 3 & & & $1.3 \%$ & $4.4 \%$ & $3.3 \%$ & $9.0 \%$ & & \\
\hline & 4 & & & & $5.9 \%$ & $12.8 \%$ & $18.7 \%$ & & \\
\hline & 5 & $0.5 \%$ & & $2.1 \%$ & $10.3 \%$ & $59.2 \%$ & $72.1 \%$ & & \\
\hline \multicolumn{2}{|l|}{ Total } & $0.5 \%$ & $\mathbf{0 . 0 \%}$ & $3 \cdot 3 \%$ & 20.8\% & $75.4 \%$ & $100.0 \%$ & & \\
\hline \multirow{5}{*}{$\begin{array}{l}\text { To enjoy } \\
\text { sun and } \\
\text { beach }\end{array}$} & 1 & & & & & & & \multirow{6}{*}{0.199} & \multirow{6}{*}{0.000} \\
\hline & 2 & & & & & & & & \\
\hline & 3 & & & $1.3 \%$ & $1.3 \%$ & $6.2 \%$ & $8.7 \%$ & & \\
\hline & 4 & & & $0.8 \%$ & $9.2 \%$ & $14.9 \%$ & $24.9 \%$ & & \\
\hline & 5 & $0.5 \%$ & & $1.3 \%$ & $10.3 \%$ & $54.4 \%$ & $66.4 \%$ & & \\
\hline \multicolumn{2}{|l|}{ Total } & $0.5 \%$ & $\mathbf{0 . 0 \%}$ & $3 \cdot 3 \%$ & 20.8\% & $75.4 \%$ & $100.0 \%$ & & \\
\hline
\end{tabular}

As shown in Table 12, a significance level of less than 0.01 has been obtained in the relationship between rest motivations and general destination satisfaction. So the motivations of tourists to rest are influenced by the level of general satisfaction. In other words, the greater the satisfaction of tourists in the destination, the greater motivation for resting. In addition, $59.2 \%$ of tourists are very satisfied and highly motivated to rest, which indicates that it is necessary to improve the rest services to increase the motivations of tourists to visit the destination. On the other hand, a significance level of less than 0.01 has been obtained in the relationship between the motivations for enjoying the sun and the beach and the general satisfaction of the destination. So the motivations of tourists to enjoy the sun and the beach are influenced by the level of overall satisfaction. In other words, the greater the satisfaction of tourists in the destination, the greater the motivation for enjoying the sun and the beach. In addition, $54.4 \%$ of tourists are very satisfied and have high motivations for the enjoyment of the sun and the beach, which indicates that we must improve the services involved in the enjoyment of the sun and the beach to increase the motivations of tourists for visiting the destination. What ratifies studies as Carvache-Franco et al. (2018) that the main motivations in this typology of tourism revolve around enjoying the sun and the beach, and rest. 
The tourist demand from the perspective of the motivation, assessment and satisfaction in a sun and beach destination: The Manta case, Ecuador

\section{CONCLUSION}

The study of demand in sun and beach destinations brings important information to develop products according to their motivations, valuation and satisfaction of its travelers. These destinations have their own natural and cultural characteristics that make every time more research is done for having the largest share of the world market. The findings show that the main motivations of tourists are Resting, Enjoying beach and sun, and Delight with local typical gastronomy. The most valued aspects of the visit were Residents' hospitality, Sun and beach, and Restaurant service. The satisfaction of the destination is high, which shows the potential of this destination for this type of tourism. The variables that have a greater influence on overall satisfaction are security, information and signage, restaurant services and places of recreation. In addition, the intentions of returning to the destination are influenced by satisfaction. The motivations of tourists to relax are influenced by the level of general satisfaction. Also, the motivations of tourists to enjoy the sun and the beach are influenced by the level of general satisfaction. From a theoretical perspective it has been found that motivations such as resting, enjoying the sun and the beach are still the main ones in sun and beach destinations (Martínez, 2001, Rivas, 2004, González et al., 2006, Bigné et al., 2007; Carvache-Franco et al., 2017). In addition, the intentions of returning to the destination are influenced by satisfaction (Zabkar et al., 2009, Chen \& Chen, 2010). As practical implications it is recommended that the destination focuses on improving security, information and signaling, restaurant services and recreation places because they are variables with the greatest influence on overall satisfaction. It is also necessary to pay attention to the motivations to rest, enjoy the sun and beach, and the typical cuisine to improve the stay of the tourist. It is suggested to take into account the less valued aspects of the destination such as flora and fauna, and cultural aspects to create improvement plans that relate these variables to the visit of tourists. As a final conclusion it can be established that the main limitation of the study is the timeliness of the field study and a new line of research is opened about the relationship between the motivations of body and mind with the variables of assessment of the destinations with these natural characteristics.

\section{REFERENCES}

Bigné, E., Sánchez, I., \& Currás, R. (2007). The role of the image of the destination in the valuation and postpurchase behavior of the sun and beach tourist. Papers de Turisme, 42, 57-73.

Bramwell, B. (2004). Mass tourism, diversification and sustainability in southern Europe's coastal regions. In: Bramwell, B. (ed.) Coastal Mass Tourism: Diversification and Sustainable Development in Southern Europe. Channel View Publications, Clevedon, UK, pp. 1-31

Carvache-Franco W., Torres-Naranjo M., \& Carvache-Franco M. (2017). Profile and satisfaction analysis of tourists who visit Montañita-Ecuador. Cuadernos de Turismo. (39), 113-129.

Carvache-Franco, M., Carvache-Franco, W., Macas, C., \& Orden, M. (2018). Motivations, Valuation and Satisfaction of the Tourist in a destination of Sun and Beach of Ecuador. Revista Espacios. 39 (13), 4-16

Chen, C., \& Chen, F. (2010). Experience quality, perceived value, satisfaction and behavioral intentions for heritage tourists. Tourism Management, 31, 29-35.

Chi, C. G. Q., \& Qu, H. (2008). Examining the structural relationships of destination image, tourist satisfaction and destination loyalty: An integrated approach. Tourism management, 29(4), 624-636.

Cong, L. (2016). A formative model of the relationship between destination quality, tourist satisfaction and intentional loyalty: An empirical test in Vietnam. Journal of Hospitality and Tourism Management, 26, 50-62.

Crompton, J. L. (1979). Motivations for pleasure vacation. Annals of Tourism Research, 6(4), 408-424.

Crompton, J. L., \& McKay, S. L. (1997). Motives of visitors attending festival events. Annals of Tourism Research, 24(2), 425-439.

Cruz, E. C., Nápoles, Y. N., \& Ramos, E. E. C. (2012). Perceived image - satisfaction. The analogy to please the client: study for the Canadian market at the Hotel Blau Colonial, Jardines del Rey, Cuba. Estudios y perspectivas en turismo, 21(3), 706-728.

Dann, G. M. (1977). Anomie, ego-enhancement and tourism. Annals of Tourism Research, 4(4), $184-194$.

Das Chagas, M. M., \& Marques Júnior, S. (2011). Quality dimensions as a background to satisfaction and fidelity to sun and beach tourism destinations: A case study in Natal, Brazil, on the perception of national tourists. Estudios y perspectivas en turismo, 20 (6), 1431-1448. 


\section{Mauricio CARVACHE-FRANCO, Orly CARVACHE-FRANCO, Wilmer CARVACHE-FRANCO, Cesar VILLAGÓMEZ BUELE, Marina ARTEAGA PEÑAFIEL}

Decentralized Autonomous Government of Manta (2016). Updating of territorial development plan with special emphasis on risk management Manta 2019. Manabí, Ecuador.

De Nisco, A., Mainolfi, G., Marino, V., \& Napolitano, M. R. (2015). Tourism satisfaction effect on general country image, destination image, and post-visit intentions. Journal of Vacation Marketing, 21(4), 305-317.

Dolnicar, S., \& Ring, A. (2014). Tourism Marketing Research: Past, present and future. Annals of Tourism Research, 47, 31-47.

González, A., Sánchez, I., \& Sanz, S. (2006). Characterization of the sun and beach tourist: a comparison with rural and cultural tourists. In IX University and Business Tourism Congress (Sun, beach and residential tourism), Castellón.

Grönroos, C. (2009). Marketing as a promise management: regaining customer management for marketing, Journal of Business \& Industrial Marketing, 24 (5/6), 351-359.

Hosany, S., \& Witham, M. (2010). Dimensions of cruisers' experiences, satisfaction, and intention to recommend. Journal of Travel Research, 49(3), 351-364.

Hsu, C. H. C., Cai, H. L. A., \& Li, M. (2010). Expectation, motivation, and attitude: A tourist behavioral model. Journal of Travel Research. 49(3), 282-296.

Iso-Ahola, E. S. (1982). Toward a social psychological theory of tourism motivation: A rejoinder. Annals of Tourism Research, 9(2): 256-262.

ITB. (2016). ITB World Travel Trends Report 2015/2016. Retrieved from http://www.itbberlin.de/media/itb/ itb_dl_all/itb_presse_all/WTTR_ITB2016_8_Web.pdf

ITB. 2017. ITB World Travel Trends Report 2016/2017. Retrieved from http://www.itbberlin. de/media/itb/itb_dl_all/itb_presse_all/World_Travel_Trends_Report_2016_2017.pdf

Kozak, M. (2002). Comparative analysis of tourist motivations by nationality and destinations. Tourism management, 23(3), 221-232.

Martínez, R. (2001). Approximation to the study of the almerian tourism sector: Analysis of the offer and demand in high season. Cuadernos de Turismo, 7, 81-91.

Maslow, A. H. (1943). A theory of human motivation. Psychological Review, 5o(4), 370-396.

Moliner Velázquez, B., Gil Saura, I., \& Ruiz Molina M. (2011). Conceptualizing and measuring loyalty: towards a conceptual model of tourist loyalty antecedents. Journal of Vacation Marketing, 17 (1), 65-81.

Orams, M.B., \& Lück, M. (2013). Marine systems and tourism. In A. Holden \& D. Fennell (Eds.). A handbook of tourism and the natural environment (pp. 170-182). London: Routledge

Plog, S. C. (1974). Why destination areas rise and fall in popularity. Cornell Hotel and Restaurant Administration Quarterly, 14(4), 55-58.

Poon, A., 1993. Tourism, Technology and Competitive Strategies. CABI, Wallingford.

Prebensen, N., Skallerud, K., \& Chen, J. S. (2010). Tourist motivation with sun and sand destinations: satisfaction and the wom-effect. Journal of Travel \& Tourism Marketing, $27(8), 858-873$.

Privitera, D., Nedelcu, A., \& Nicula, V. (2018). Gastronomic and food tourism as an economic local resource: case studies from Romania and Italy. GeoJournal of Tourism and Geosites, 21(1), 143-157.

Rivas, J. (2004). Structure and Economy of the Tourist Market. Oviedo: Septem Ediciones.

Saayman, M., Slabbert, E., \& Van Der Merwe, P. (2009). Travel motivation: a tale of two marine destinations in South Africa. South African Journal for Research in Sport, Physical Education and Recreation, 31(1), 81-94.

Safee Sapari, M., Shuib, A., Ramachandran, S., \& Syamsul Herman, M. (2013). Visitor's satisfaction towards service and facilities in Kilim Karst geoforest park, Langkawi. Journal of applied Economics and Business, 1(4), 25 - 42

Suni, J., \& Komppula, R. (2012). SF-Filmvillage as a movie tourism destination-a case study of movie tourist push motivations. Journal of Travel \& Tourism Marketing, 29(5), 460-471.

Torres-Sovero, C., González, J., Martín López, B., \& Kirkby, C. (2012). Sociale-ecological factors influencing tourist satisfaction in three ecotourism lodges in the southeastern Peruvian Amazon. Tourism Management (33), 545 - 552.

Uysal, M., Gahan, L., \& Martin, B. (1993). An examination of event motivations: A case study. Festival Management \& Event Tourism, 1(1), 5-10.

Van der Merwe, P., Slabbert, E., \& Saayman, M. (2011). Travel motivations of tourists to selected marine destinations. International journal of tourism research, 13(5), 457-467.

Yolal, M., Rus, R. V., Cosma, S., \& Gursoy, D. (2015). A pilot study on spectators'motivations and their socioeconomic perceptions of a film festival. Journal of Convention \& Event Tourism, 16(3), 253-271.

Yüksel, A, Yüksel, F. \& Bilim Y. (2010). Destination attachment: effects on customer satisfaction and cognitive, affective and conative loyalty. Tourism Management, 31, 274-284.

Zabkar, V., Brencic, M. M., \& Dmitrovic, T. (2009). Modeling perceived quality, visitor satisfaction and behavioural intentions at the destination level. Tourism Management, 31, 537-546.

Žabkar, V., Brenčič, M., T. \& Dmitrovič, T. (2010). Modelling perceived quality, visitor satisfaction and behavioural intentions at the destination level. Tourism Management, 31, 537-546.

Submitted:

27.06.2018
Revised:

07.09.2018
Accepted and published online

11.09.2018 